\title{
Improved Policies for Facilitating the Adoption of Agroforestry
}

\author{
Frank Place ${ }^{1}$, Oluyede C. Ajayi ${ }^{1}$, Emmanuel Torquebiau ${ }^{2,3}$, \\ Guillermo Detlefsen ${ }^{4}$, Michelle Gauthier ${ }^{5}$ and Gérard Buttoud ${ }^{6}$ \\ ${ }^{1}$ World Agroforestry Centre, Nairobi \\ ${ }^{2}$ Centre de Coopération Internationale en Recherche Agronomique pour le Développement \\ (CIRAD), UR 105, Montpellier \\ ${ }^{3}$ Centre for Environmental Studies (CFES), University of Pretoria, Pretoria, \\ ${ }^{4}$ Centro Agronómico Tropical de Investigación y Enseñanza, Turrialba, \\ ${ }^{5}$ Food and Agriculture Organization of the United Nations (FAO) \\ ${ }^{6}$ University of Tuscia and FAO \\ ${ }^{1}$ Kenya \\ ${ }^{2}$ France \\ ${ }^{3}$ South Africa \\ ${ }^{4}$ Costa Rica \\ 5,6Italia
}

\section{Introduction}

\subsection{The increasing importance of agroforestry as a major land use practice}

There is now general agreement about the magnitude and scale of the integration of trees into agricultural lands and their active management by farmers and pastoralists. Zomer et al. (2009) conducted a global assessment of tree cover on agricultural land and found that $48 \%$ of all agricultural land had at least $10 \%$ tree cover. A high percentage of tree cover is found in nearly all continents of the world, highest being in Central America and southeast Asia. Although Africa shows a smaller percentage of tree cover at continental level, the most widespread farming system in Africa is the so-called agroforestry parkland (scattered trees in cropland), making Africa a typically "treed continent" in agricultural areas (Boffa, 1999). The FAO Forest Resources Assessment Report has integrated since 2000 the assessment of trees outside forests, which consist mainly in agroforestry systems as well as tree systems in urban areas. More countries are now measuring and reporting trees outside of forests and country provided data indicate that such areas are significant. For example such area is greater than forest area in countries such as Kenya, Tunisia, and Niger and is a high percent in many others including temperate countries (FAO, 2011a). Evidence on the significance of specific agroforestry systems (e.g. agroforests in Indonesia, farmer managed parklands in Africa, treed rangelands, scattered trees on pastures and shade trees with plantation crops such as coffee and cocoa in Central America, Brazil or Cameroon) or practices (e.g. widespread fodder shrubs and trees in semi-arid and sub-humid Africa or in East Asia, fruit growing in Kenya) is also available in a large base of literature. 
The economic importance of agroforestry can be partly understood by examining data on the export value of major tree products. Drawing upon data from FAOSTAT (2011), Table 1 shows that conservative estimates of international trade of this list of tree products was valued at a whopping US\$140 billion in 2009. The actual production levels are much higher, considering that the list includes only well known and common tree products and that many tree products in developing countries are not marketed internationally (e.g. firewood, fodder, medicinal uses) and for products such as fruit, as much as $90 \%$ of production is consumed domestically. In addition, the positive externalities (or ecosystem services) represented by trees (e.g. carbon sequestration, nutrient cycling, provision of shade, etc.) are not counted.

\begin{tabular}{|c|r|r|r|r|r|r|}
\hline Commodity & $\mathbf{2 0 0 1}$ & $\mathbf{2 0 0 3}$ & $\mathbf{2 0 0 5}$ & $\mathbf{2 0 0 7}$ & $\mathbf{2 0 0 8}$ \\
\hline Coffee & 8661842 & 9769085 & 15637891 & 22061510 & 26800406 \\
\hline Citrus & 7709475 & 10217484 & 11597821 & 15869879 & 17689609 \\
\hline Cocoa & 2208064 & 4200355 & 4954083 & 5708236 & 7246038 \\
\hline Tea & 2820992 & 2942887 & 3582778 & 4042636 & 5520560 \\
\hline Coconut & 895924 & 1210337 & 1876246 & 1996676 & 2895301 \\
\hline Cashew & 947931 & 1118091 & 1850100 & 2025783 & 2735722 \\
\hline Natural rubber & 428511 & 808637 & 1055177 & 1910370 & 2052320 \\
\hline Avocado & 320124 & 545553 & 844884 & 1281887 & 1279566 \\
\hline Mango & 428299 & 578874 & 646821 & 918524 & 1001681 \\
\hline Oil of Castor Beans & 162196 & 158904 & 254711 & 363456 & 566613 \\
\hline Cinnamon & 107135 & 109066 & 139606 & 185115 & 199092 \\
\hline Papaya & 124014 & 161481 & 185248 & 186153 & 188050 \\
\hline Fig & 23073 & 38283 & 44751 & 57030 & 83125 \\
\hline Shea kernel & 10452 & 22807 & 7167 & 30399 & 42410 \\
\hline Plant-based Gums & 6628 & 11656 & 8311 & 6747 & 6513 \\
\hline Kolanut & 6932 & 1668 & 477 & 1916 & 1904 \\
\hline
\end{tabular}

Table 1. The global export value of some major tree products (in US \$1000's) Source: Compiled from FAOSTAT (2011)

In another testament to the importance of agroforestry, FAO (2003) observed that forest cover in Africa continues to decrease while tree cover on farms is increasing. Indeed, it is reasonable to expect the demand for tree products including export values as shown in Table 1 to continue to increase. The importance of smallholder agroforestry is only likely to be reinforced with increased attention and resources to climate change adaptation and mitigation whereby more efforts are being made to protect forests while simultaneously expanding tree growing on farms. In some parts of the world (e.g. Southern Africa), an upward trend in tree density in savanna landscapes has been observed in recent years (possibly linked to climatic variables such as rainfall and CO2 levels) and may further reinforce the importance of trees in the livelihoods of local people (Bond et al., 2003; Kgope et al., 2010; Midgley and Thuillier, 2011).

The data presented above paints a very positive picture of the spread of agroforestry. Yet the general trend masks some important caveats, areas where agroforestry has not developed or spread with much vigor. Many locations are in desperate need of more trees for fuelwood (e.g. much of Ethiopia or Bangladesh) and for improved catchment protection 
(e.g. wide areas of India). While some areas have thriving fruit growing systems (e.g. South Africa, Kenya, India), others still exhibit poor production figures and very low consumption (e.g in Southern Africa). Tree growth and productivity is often low and variable due to lack of access to better quality germplasm. Furthermore there are many missed opportunities for reducing the period to full production by disseminating advanced propagation methods. Some more innovative and new ways of managing trees on farms (e.g. intercrop systems for soil health) are yet to be known by the vast majority of farmers. Lastly, and most importantly, while some countries have found tree growing to be enormously profitable others do not even consider it as a potential livelihood. In fact, the study by Zomer et al. (2009) shows that there exist many landscapes across the globe where tree cover is less than expected given the rainfall characteristics of the landscapes.

The evidence suggests that policy plays an important role in distinguishing countries and regions which have benefited greatly from agroforestry from those who have not. Three policy areas appear to be most important. The first concerns essential long term private property rights over land and trees. Where these have been absent or contested, tree planting and management by farmers has been limited. Second, policies related to tree germplasm multiplication and dissemination are important in facilitating expansion of agroforestry. Finally, the recognition of agroforestry as an attractive investment area within agricultural institutions and programmes is also important. The remainder of this chapter explores this role in more detail. To set the context, section 2 reviews recent experiences in expanding agroforestry in order to understand some of the challenges involved in scaling up agroforestry systems. Based on these case studies and other literature, section 3 then discusses in detail key policy areas that hinder or promote the impact and adoption of agroforestry. Section 4 then presents examples of recent policy reforms that have been favorable for agroforestry and the final section concludes with key messages.

\section{Lessons learnt from previous efforts to promote agroforestry in different countries}

Although some agroforestry systems have been practiced for generations, others, have been designed or adopted more recently. This section analyses the factors behind some of these recently adopted systems. In particular, how was awareness created, knowledge disseminated, and germplasm made available? What were the key success factors and roles of private sector, NGOs, government and other actors? It is useful to begin by describing in more detail some of the characteristics of agroforestry systems that have recently been upscaled. Some could be characterized as having some foundation in the farming traditions. For example, it could be a modification of an existing practice - e.g. different species but managed in a familiar way. Others could be much more novel to farmers - e.g. the introduction of improved fallows is a completely new way of farming in most areas. This distinction is important in terms of the requirements placed on activities such as awareness creation and dissemination of technical management information and skills. The introduction of a new fruit cultivar may require awareness raising, but little technical training if farmers are already managing fruit trees. So this key distinction should be kept in mind in the following discussion.

In the majority of cases reported below, the main objective of the promotion of agroforestry was to increase private benefits for smallholder farmers. Thus, the particular agroforestry 
systems and species were expected to provide benefits such as wood products, fruits, fodder, and improved soil fertility which would benefit farmers directly. Where farmers do perceive private benefits the demand for agroforestry knowledge and germplasm will be higher than in the absence of such benefits. However, there is increasingly more promotion of agroforestry for other benefits as well, such as for environmental services that may accrue to broader society. These include watershed protection, biodiversity and carbon sequestration. Dissemination of agroforestry systems and species to meet these needs will face similar challenges to those aimed more towards private benefits (and many agroforestry can simultaneously provide both, as noted in the introduction). However, there are additional challenges in that incentive systems for farmers to produce societal level benefits need to be established and clarified to farmers (Leimona, 2011)

\subsection{Awareness creation}

As may be expected, awareness creation for agroforestry has involved a variety of actors. In the case of the farmer-managed natural regeneration agroforestry practice in Niger, the NGO (Serving in Mission) who pioneered the approach in the Maradi region was also instrumental in creating awareness beyond the initial locality (Reij et al., 2009) and was soon joined by CARE in the promotion of these practices. The World Agroforestry Centre (ICRAF) played a significant role in the development of fertilizer tree and fodder shrub options for the Sahel (Torquebiau and Moussa, 1990, 1991) and then later became a key driver for the same in East and Southern Africa (Ajayi et al., 2007a). Likewise, ICRAF and national partners in Tanzania helped to scale up a local practice of regeneration called ngitili modified partly by purposeful selection and planting of valuable trees (Pye-Smith, 2010). In all these cases, projects were an important vehicle in awareness creation (and also for training on technical knowledge). The case of the wide scale dissemination of Faidherbia albida and conservation agriculture in Zambia had strong participation by the private sector (Donavant cotton), the government (Conservation Farming Unit in the Ministry Agriculture), and the national farmers' association (Garrity et al., 2010; Haggblade and Tembo, 2003;). The private sector seems to have played a more significant role in the awareness creation for agroforestry practices that produce relatively higher value product. This can be seen in the case of the rapid expansion of poplar growing by smallholders in India, where wood processors in Haryana State were critical in awareness creation and eventually also in supplying seedlings (Zomer et al., 2007). Unilever is investing significantly in the more recent upscaling of Allanblackia, which produces an oil with properties that are attractive for a range of food products (Pye-Smith, 2009). The more gradual expansion in the number of fruit growers and fruit varieties grown in Kenya was also influenced considerably by the private sector, including companies and trade associations. A strong parastatal agency for horticulture also played a key role.

So there is clearly no single pathway to creating awareness. Governments have not often been involved in these examples, most likely due to the problems of agroforestry being neglected or not championed by a single government ministry (see below). However, this appears to be changing particularly with the increased importance of climate change and the embracing of agroforestry as a key climate smart practice. It is positive that the private sector has been involved in creating awareness of agroforestry opportunities. Their involvement is accompanied by value chain development which is critically needed for many agroforestry products. Recent announcements by Coca-cola, Pepsi, and Del Monte, that they were all 
interested to invest in developing smallholder fruit market chains in East Africa are a further sign of potential upscaling in the region. Chocolate companies aiming to purchase certified cocoa have played a similar role for the development of tree shaded cocoa cultivation.

\subsection{Dissemination of technical knowledge and skills}

Many recently developed agroforestry systems are novel in terms of management compared with conventional practices which farmers are more familiar with and which they have received training for a longer period. Human capacity, infrastructure and institutional supports for agroforestry systems are low in most national extension programs (Ajayi et al., 2009). As a result, the same actors involved in awareness creation are often also involved in the greater efforts to build knowledge and skills capacities to manage the agroforestry systems. A major effort was undertaken in Central America to improve the technical skills of extension agents in agroforestry. A Central American Tree Manual was produced to provide information on both important agroforestry practices and nearly 200 indigenous species (Cordero and Boshier, 2004). To ensure uptake, the manual was distributed through a programme of free courses. More than 1000 extensionists of the seven countries of region were trained from 2003 - 2005 under a multiplier effect, covering a mix of foresters, agroforesters, agronomists and extensionists from rural development agencies (Boshier et al., 2009).

In the African examples, much more attention to dissemination of knowledge needed to be given to new practices such as fodder and fertilizer tree systems. A number of different approaches were tried in the various African sites where these were disseminated. Given the limited number of government extension staff, upscaling has tended to emphasize models that rely on farmers and farmer groups to help disseminate information. The farmers are in turn trained and supported by resource persons that are normally paid by a project or programme. This approach is very cost effective, as farmer trainers often train many other farmers (Franzel and Wambugu, 2007). Moreover, those who have been trained, often pass on information. The concern with such an approach is that the farmer trainers are not remunerated well (or at all) and therefore their commitment may be expected to wane over time. In Zambia, where there is a committed support structure and financing for conservation agriculture with trees, there has been impressive scaling up to more than 100,000 farmers. A similar model was first tested by ICRAF for fodder shrubs in East Africa and the approach has been incorporated into a larger development project running for the past 4 years. The effectiveness of such approaches contrasts with the Farmer Field School approach, which is recognized as effectively training farmers, but not reaching many for a given amount of funds (Feder et al., 2003). The farmer trainer method is new and is only being evaluated now. Therefore, while such an approach has clearly facilitated the wide spread of agroforestry, it remains to be seen whether it has provided sufficient depth in the dissemination to result in large benefits for adopting farmers.

\subsection{Germplasm inputs}

In all cases, these recent scaling up efforts have tried to use the private sector, including farmers themselves, in the collection of seed and production of tree seedlings. In the case of India, the private sector invested in production of high quality seedlings that were given on credit to farmers. This had multiple benefits - to quicken the pace of adoption and supply of wood, to ensure that quality of the wood was sufficient, and therefore to increase the profit 
potential for the farmers so as to create a sustainable sector. Similarly, timber and fruit seedlings are being produced and sold by private sector nurseries in many countries in the world. For new agroforestry systems such as fertilizer trees and fodder shrubs, a demand needed to be created before private sector supply could be expected to respond. So in initial phases, seeds were supplied freely by projects for demonstration purposes. As local demand grew, ICRAF and other NGOs withdrew from bringing in seeds externally but rather encouraged local seed collection and later local seedling production, by playing middlemen and then broker roles. Demand for fodder shrubs in Kenya became so high that stakeholders agreed to form an agroforestry tree seed association which would facilitate the bringing together of suppliers and demanders of fodder shrub seed. Seed and seedling systems for fertilizer tree systems are still not well privatized. The densities of trees required (up to 10,000 per hectare), the reduced importance of quality seed (as compared to the quality of a fruit or timber tree), and the fact that they provide an input service role rather than a valued product of their own, means that farmers' interest in paying for seed is rather low. So NGOs or other intermediaries still play a significant role in fertilizer tree seed supply.

While there are strong movements towards privatization in seed supply globally, there remains heavy involvement by governments in some instances. In Ethiopia, the government has played an active role in all facets of upscaling tree planting including the establishment of government nurseries and sales at subsidized rates. In many, if not most countries, governments become directly involved in providing seed and seedlings for tree planting efforts in non-agricultural areas, for example on hillsides to provide watershed protection services. The Kenya government is considering various options related to agroforestry tree seed and seedling supply to meet the newly enacted regulation that all farms must have $10 \%$ tree cover.

\section{The importance of policy for agroforestry}

The adoption or lack of adoption of agroforestry is influenced by a variety of factors. Some have relatively little to do with policy -- including climate conditions (e.g. rainfall), household and farm characteristics (e.g. resource endowment, size of household), and attributes of the particular agroforestry technology (e.g. time lag between costs and benefits) (Ajayi et al., 2007b). However, a number of important factors are directly linked to policy. In some cases, these policy 'failures' can be over-riding of others and their alleviation critical to wider adoption. This is the first justification for why adoption of agroforestry is a policy issue. The second reason why the adoption of agroforestry is a policy issue is that agroforestry generates significant public environmental services such as watershed protection, biodiversity, and carbon sequestration for which market failures exist. The result is that without government involvement in providing greater incentives, the level of private investment in agroforestry will be less than socially optimal.

In the following paragraphs, the key policy-related constraints to agroforestry adoption are discussed, in no particular order of importance.

\subsection{Property rights - Land tenure}

Due to the longer period (relative to annual crops) through which farmer testing, adaptation and eventual "adoption" of agroforestry technologies takes place (Mercer, 2004; Scherr and 
Müller, 1991), the importance of property rights is greater than for many other types of agricultural enterprises or practices (Place and Swallow, 2002; Ajayi and Kwesiga, 2003). In some places, long term rights to land are insufficient to motivate long term investments such as agroforestry. This can manifest itself as conflicts between the state and land users, such as is the case in smallholder communities within de jure forest land of Indonesia and the Philippines. State ownership of land and reallocation programmes have also been found to inhibit long term land investments in places such as Ethiopia prior to more recent land tenure reforms there. Recent attempts by governments to attract large scale foreign investors have heightened insecurity of rural communities in many countries. Lack of long term rights may also emerge from conflicts between ethnic groups, between indigenes and settlers, families or members of families. Generally, land rights on farm land become more privatized as population pressure increases or commercial opportunities increase. This mainly has a positive effect on incentives for long term investment, but limited rights can arise in such cases if short term land transactions such as land renting become common. While historically the planting of trees was used by farmers to increase tenure security where it was low, this phenomenon is decreasing as inheritance and purchase of land become much more common than allocation by a traditional chief.

Regardless of the overall land security of farming households, in general, women's rights to land and trees are almost always inferior to those of males. This was found to be the case in studies of Uganda, Burundi, and Zambia (Place, 1995). Even in matrilineal societies, the decision making power of women viz tree planting is not guaranteed, such as in Malawi (Hansen et al., 2005; Place and Otsuka, 2001).

Moving from the farm to the other patches of land in and around communities, Elinor Ostrom has shown that the tragedy of the commons is not a universal rule and that privatizing natural resources is not the route to halting environmental degradation and providing equitable access to resources (Ostrom, 1990). Under certain conditions, when communities are given the right to self-organize they can democratically govern themselves to preserve the environment. Where common property resources provide products such as firewood, fodder and thatch, there are many examples of sustainable management (Otsuka and Place, 2001).

\subsection{Tree tenure}

Forest policies inhibit tree growing on farms by regulating harvesting, cutting or sale of tree products and certain tree species. Although sometimes well intentioned, such protective policies, when applied to agricultural landscapes, discourages farmers from planting and protecting new seedlings that emerge. Such policies are found in all tropical continents and were perhaps most critically noted in their inhibiting role in Niger and generally in the Forest Codes of West African countries (Elbow and Rochegude, 1990). Restrictions against the felling of trees on farmers' lands are common under forest regulations ranging from India (national and state levels) to Reserved Species in Uganda (Government of Uganda, 2001). Honduras, Nicaragua and Panama have very strict regulations for timber harvesting in agroforestry system and one result is the loss of interest of farmers to associate trees with crops and / or pastures (Detlefsen and Scheelje, 2011).

It is ironic that this important direct source of funds for foresters should result from tree cutting rather than tree growing or tree cover, as transpires in Mali, India and in the Central 
American region. Further, when rigid enforcement of such restrictive policies are relaxed, as in the case of Niger, there can be a swift and vast response, resulting in millions of hectares of parklands with young trees. Also, poor regulation of state managed woodlands and forests have led to undervaluing of concessions or stumpage charges resulting over supply from these sources and under supply from farms. Charcoal is a good case in point. The sector, which is largely unregulated in Africa, is characterized by mobile charcoal burners, seeking the cheapest sources of wood as possible, and who have no long term interest in the sustainable use of any particular piece of land. If charcoal producers paid a fair price for their wood sources in woodlands/forests, this would increase opportunities for farmers to supply trees for charcoal makers. This shows how tenure rules on non-farm areas have an implication for agroforestry on farms.

\subsection{Agroforestry tree germplasm systems}

The problems observed in the agroforestry tree germplasm sector are numerous: narrow base of tree germplasm which is available in areas outside of growing areas, little multiplication of this narrow base so that quantities available for all species are low, the quality of the germplasm is low on average and variable, with little investment in germplasm improvement, and retail level systems - interfaces with farmers are not well developed and are challenged by competition between private and public sector involvement. Seed collection, propagation and multiplication methods are also poorly known and farmers often have no other option but to protect or transplant trees which have germinated spontaneously.

Part of the neglect of the sector has to do with the fact that in most developing countries forest departments have the mandate for all tree seed supply. This is sensible for forests and plantations, but has serious drawbacks for agroforestry species because resident forestry staff are few in the field and are not highly aware of needs of farmers. Agricultural extension staff have a much better understanding of farming systems and potential utility of integrating trees on farms. So this is a critical structural gap which remains problematic in many countries despite efforts of some programmes and projects to better involve the agriculture sector in agroforestry. Another challenge is that governments and NGOs often give away free or subsidized seed and seedlings which competes against entrepreneurs.

Although most agroforestry stakeholders would agree on the need for more private sector involvement in seed/germplasm supply systems, there are numerous constraints. One is related to the business nature of tree demand. Unlike annual crops, farmers may purchase tree seed or seedlings just a few times in their lives. Second, where seedlings are used, the market area is limited by ability to transport seedlings within a reasonable time period (to avoid damage to the seedling) and at an affordable cost. So demand limitations can reduce the interest in retail germplasm supply as a profession. There are also information problems concerning the quality and source of germplasm. It is not easy to discern different varietial type or other quality features of seed or young seedlings and this hampers the ability of suppliers to charge prices commensurate with quality. There are some exceptions, such as with the development of market chains for eucalyptus seedlings and some fruit cultivars. But generally, the sector is beset by market failure problems that require attention by policy makers.

However, a lot remains to be done in terms of germplasm diversification. There is no consolidated global picture on the status and trends of tree genetic resources, and a lack of 
estimators of the rate of genetic diversity loss. This limits the capacity of countries and the international community to integrate tree genetic resources management into overall crosscutting policies. The State of the World's Forest Genetic Resources, in preparation by FAO will publish specific information on the status and trends in forest genetic resources (FAO, 2009). Despite limitations on understanding of genetic diversity, multipurpose trees have now been identified for most regions of the world, though many of these trees are actually never brought into cultivation. They are protected when they germinate naturally in fields (as typically in the African agroforestry parkland), or they are simply used from the wild. The seed technology of many species is simply not known and there are few nurseries providing a range of native multipurpose trees. Out of the more or less 40,000 tree species which make the tropical tree flora, it is probable that a few hundred, at most, are cultivated. The policy context to support a wider use of multipurpose tree germplasm has to be invented from scratch. Depending on the location, policy options could be subsidies to nurseries, germplasm collection campaigns funded by the private sector or validation of local ecological knowledge.

\subsection{Subsidies or support for other land use practices}

There are many governments that have put in place price floors for food products, subsidies for specific inputs like fertilizer, or favorable credit terms for certain agricultural activities. These almost always exclude agroforestry and therefore discourage its practice. In the case of fertilizer, for example, such government policies induce higher use of fertilizer and less interest in using more sustainable practices like agroforestry. Several years ago, fertilizer tree technology was considered impractical or less economically rational to use in Nigeria because nitrogen fertilizers were a cheaper option at that time (Sanchez, 1999). Fertilizer subsidies have been present for decades in Asia and are making a comeback in Africa (e.g. Malawi, Zambia, Tanzania, Kenya and more recently Nigeria). There is little argument that fertilizers are needed in agriculture, but by subsidizing them without commensurate support for other soil fertility measures such as agroforestry-based fertilizer trees, governments risk promoting a narrow technological package that is not compatible with long term soil health. Many governments support agriculture in some ways, but agroforestry is not often included as an agricultural enterprise for support. For example, in India, credit at low rates is available for agriculture, but agroforestry falls under 'forestry' and faces a much higher interest rate. The same situation was observed in France as far as CAP subsidies are concerned until the development of a very innovative new policy for the country where agroforestry trees are considered as inputs into farming practices, making agroforestry fields eligible for CAP subsidies while they were considered as "forests" under the earlier regulation, and consequently not eligible. Many governments have now improved market information systems for agricultural commodities but again, tree products are usually neglected.

Through economic policies, governments also can significantly influence resulting land use patterns. For example, the Indonesia government provided tax and land tenure benefits for large scale farmers to convert forest land into oil palm. The further development of this sector then led to conversion of traditional agroforests to oil palm. In India (Kerala), specific agroforestry policies do not exist to guide planning and the consequence is that existing land tenure, agriculture and forestry policies favor monospecific plantation crops (Guillerme et al., 2011). Mono-specific tree crop systems are further promoted by the 
development and testing of tree crop varieties under full sun conditions only, ignoring the potential for improved varieties in more multi-species agroforestry systems. An example is the case of rubber in Indonesia (Williams et al., 2001).

\subsection{Extension systems}

Studies from several countries in Africa have shown that sustainable land management practices such as agroforestry are not sufficiently known by extension agents and much less likely to be disseminated to farmers (e.g. in Zimbabwe - Chitakira and Torquebiau, 2010; in Nigeria - Banful et al., 2010; in Zambia- Sturmheit, 1990). This creates an information bias towards other types of practices. Indeed, the transmission of new management practices to frontline extension workers has long been acknowledged as a difficulty, especially in Africa. Some agroforestry practices are knowledge intensive and thus do not diffuse as quickly as other technologies. Part of the explanation for this with respect to agroforestry is that silviculture is the domain of forestry officers and agricultural extension messages emphasize conventional crop husbandry methods. Even where extension agents are trained, they often are understaffed and cannot easily meet the time commitments required to fully train farmers on new farming methods like agroforestry.

\subsection{National government and programme structure}

Agroforestry has a de facto "orphan" status in many national government settings (some Central American countries are exceptions where agroforestry is more widely recognized); agroforestry in principle is important to many ministries but in practice, it belongs to none. Agroforestry was first attached to the forestry sector but forest departments have historically had relatively few resources for programmes, been unfamiliar with agricultural practices, and often played a more policing than advisory role. Agriculture is the natural home for this farmer practice and there is a noticeable shift of agroforestry towards agriculture, especially as the soil fertility benefits of agroforestry have become more well known. Thirty years ago, one would be pressed to find agroforestry articulated in any national policy or strategy document. Now, as it is gaining recognition, it is increasingly mentioned. There are references to agroforestry in forest acts (e.g. Kenya), but often it receives minor attention with natural forests and plantations receiving the most attention. Thus, as noted above, when it comes to tree germplasm, there is inadequate attention paid to the needs of farmers and agroforestry trees. Agroforestry is also appearing more in agricultural strategies, but often merely in a list of options for addressing sustainability. The capacity for agroforestry to generate income is hardly ever recognized in policy documents. Recent review of policies in Malawi shows that agroforestry has a very low profile in most of the sectoral policy documents. In the national Forestry policy document, the word "agroforestry" appears only on 2 out of a total 19 pages; one page out of the 293 pages of the Malawi Growth and Development Strategy document; twice in the 210 pages of the Agricultural Sector Wide Approach (ASWAp) policy document, once only out of the 40 pages of the Livestock Policy document (Pangapanga and Ajayi, 2011). More recently, agroforestry is given strong attention in climate change adaptation and mitigation strategies, which themselves are often managed by ministries of environment. But ministries of environment often do not have capacity to support agroforestry in a meaningful way at the community level and must rely on other ministries, notably agriculture, for implementation. Yet, intersectoral planning and resource sharing is very rare. 
Lastly, it is important to note the structural challenges facing agroforestry in managed landscapes that arise from ambiguity and conflict between the mandates or capacities for governance at national and local levels. There has been devolution of control and decisionmaking authority over natural resources to local governments, but the boundaries of authority are not always clear, local level capacity is often weak, and funding for local level planning and implementation is usually given low priority compared to sectors such as education, health, water, and roads.

\subsection{Environmental services}

Agroforestry is increasingly being recognized as a key land use for the provision of environmental services, such as carbon sequestration (Smith and Martino, 2007) watershed protection and biodiversity. These externalities are sometimes spatial such as the effects of agroforestry on watershed protection for downstream users, or temporal, such as the effects of agroforestry on long term soil health and land rehabilitation. These services, or positive externalities, are not rewarded by market mechanisms (market failure) and thus the supply of these benefits is less than socially optimal levels. This is a justification for government involvement to establish or catalyze systems and mechanisms that can link consumers (buyers) of the environmental services with suppliers and to increase the efficiency of such markets (e.g. to provide guarantees, to reduce transactions costs).

\section{Policy reforms that have been pro-agroforestry}

There have been some recent policy reforms that have directly targeted and benefited the expansion of agroforestry. A good number of these are related to revisions in forest policy or its implementation. The first example was already mentioned above, the reforms which occurred in the form of re-interpretation and implementation of the Forest Code in Niger which helped to expand the practice of farmer managed natural regeneration to over 5 million hectares of land (Garrity et al., 2010). The government of Indonesia has altered policies on property rights to grant communities long term rights to forest land in return for environmental stewardship of the land (HKM programme) and have also created a village forest concept (Hutan Desa) which would provide villages rights to benefits of carbon or other environmental services (Pender et al., 2008). Guatemala recognized in the Forest Act in 1996 that procedures for timber harvesting in agroforestry systems should be simplified. Fifteen years later it is observed that farmers produce timber within their farms as another form of diversification of land use, and as another source of income (Detlefsen and Scheelje, 2011). El Salvador has now a similar recognition of agroforestry within their Forest Act (amended in 2004). In Belize, Rosa Cruz (2010) found that timber production in silvopastoral systems has large productive potential because the simplified conditions of the forest law.

Some governments have gone as far as to adopt explicit agroforestry strategies or policies. In France, constraints against agroforestry were mainly economic and linked to taxations of tree products. As long agricultural as subsidies are linked to cultivated area, farmers showed no interest in growing trees in cropland, even if there is a recognized ecological advantage and if long term income can be expected from timber. And if the land is classified as forestry land, taxation is higher. In 2010, the government of France passed an agroforestry policy whose main achievement was to establish agroforestry as a legal agricultural land use qualifying for EC agricultural subsidies in the framework of the common agricultural policy 
(CAP). Farmers can receive investment support for the establishment of the agroforestry systems on agricultural lands. Without that, all other agricultural practices were favored (APCA, 2010). Also, a national association on agroforestry was created in France to organize and exchange information, follow up with regulation reforms and increase building capacity of development agents through training programmes. The triggering factor was to stop negotiating with foresters and convince the government that trees in fields were not forestry products but inputs into the farming systems. Within the EU, review processes are underway to examine how agroforestry fits into the two pillars of agricultural support: Pillar I - direct aid and market support, and Pillar II - rural development, as well as within forestry policy schemes for farm woodlands (Organic Research Centre, 2010).

Several countries or regions are developing or refreshing agroforestry strategies. Brazil had earlier developed an agroforestry strategy in 1997 and is currently embarking on a participatory process to refresh the policy. The United States Department of Agriculture (USDA) developed an Agroforestry Strategic Framework 2011-2016 which notes the upcoming release of a policy statement on agroforestry and the establishment of an Agroforestry Steering Committee that will guide the implementation of this strategic framework (USDA, 2011). The report "Portrait of Agroforestry in Québec, Canada, recommends five preliminary strategic components: recognition of agroforestry by government and institutional decision makers; establishment of an intersectoral partnership; adoption of an economic and market development approach; solid technical and economic foundations for agroforestry development; and adequate structural and operational funding (De Baets et al., 2007).

China and India have embarked on ambitious programmes to increase tree cover outside of forests (Grain for Green and Greening India respectively), including some attention to smallholder agroforestry. In 2009, the Government of Kenya, in particular the Ministry of Agriculture, enacted new Farm Forestry rules which require 10\% of all farms to be covered with trees. This was in response to recognition of deforestation, the increase in agricultural land area, and the high motivation of farmers to plant trees. The government has also allocated several million dollars to assist farmers in regions where these targets are not already met. The Indian State of Chhattisgarh adopted an agroforestry policy in 2009 which goes as far as to include agroforestry products among several that it establishes a price floor and guaranteed market for, in order to ensure adequate production.

A number of countries have advanced agroforestry in their programmatic development as a result of increased attention to climate change. In order to make agricultural production and income more resilient to climate change and variability, transformations in the management of natural resources (e.g. land, water, soil nutrients, and genetic resources) and higher efficiency in the use of these resources and inputs for production. The key role of agroforestry for climate-smart agriculture is now cited in key publications along with institutional and policy options available to promote the transition to climate-smart agriculture at the smallholder level (e.g. FAO, 2010). The responses of governments are perhaps most explicitly observed through the development of National Adaptation Programmes of Action (NAPAs) and Nationally Appropriate Mitigation Actions (NAMAs). In the agriculture and environment sectors, agroforestry is a priority action in many countries. Support for these processes has come partly from processes at global and regional levels. The UNFCCC recognized agroforestry as a key mitigation method within agriculture (Smith et al., 2008) and methods for quantification of its mitigation potential were accepted. Similarly, African ministers of agriculture endorsed the wide scaling up of agroforestry to 
address climate change adaptation and mitigation objectives in agriculture in 2009. The Comprehensive African Agricultural Development Programme (CAADP) developed an agriculture climate change adaptation and mitigation framework which was endorsed by the same ministers in 2010 and which also highlights agroforestry.

\section{Conclusions and implications for advancing policy reforms at national level for agroforestry}

The analysis in this chapter has demonstrated that there are a number of important policy constraints that hinder wider adoption of agroforestry among smallholder farmers in developing countries, both at formulation and implementation levels. Yet, driven by rural development and environmental objectives, there is a greater policy recognition of the importance of agroforestry. This has translated into a few concrete examples of policy reforms that have removed barriers to agroforestry, resulting in positive impacts in cases where studies were conducted. Most, if not all, the policy reforms featured in section 4 were supported by research, development, and other civil society organizations in some way. For example, research played a role in advancement of the recognition of agroforestry at global and regional levels and in providing evidence to support national reforms in some cases (e.g. UNFCCC); non-governmental organizations played important roles in policy reforms as well (e.g. in Niger).

Thus, there is strong reason to believe that a more concerted and collaborative supporting effort among such organizations would lead to even greater policy impacts. The World Agroforestry Centre (ICRAF) proposed the need for an Agroforestry Policy Initiative and embraced it internally in 2009. The FAO is leading an initiative to develop agroforestry guidelines for policy makers, which would support the development of agroforestry through dissemination of good practice in policy and reform processes. The FAO is also supporting the development of a framework for trees outside forests assessment, including agroforestry, at national, regional, eco-regional and global levels, a key instrument for informed decision processes. (FAO, 2011b). A group of organizations have in fact joined forces to support national policy reforms related to agroforestry. The Centro Agronómico Tropical de Investigación y Enseñanza (CATIE) in Costa Rica, Centre de Coopération Internationale en Recherche Agronomique pour le Développement (CIRAD) of France and ICRAF have joined forces with FAO in this endeavor. The three organizations have large agroforestry research programmes spanning all developing regions of the world. This vast experience complements very well the strength of FAO in linking science to policy action through its convening power at global and country levels. It is hoped that the production of the guidelines along with other efforts by countries and institutions will catalyze an even wider partnership and movement towards removing policy barriers that have hitherto constrained agroforestry from reaching its full potential.

\section{References}

Ajayi, O.C., Akinnifesi, F.K., Sileshi, G., Chakeredza, S. \& S. Mgomba. 2009. Integrating Food Security and Agri-environmental Quality in Southern Africa: Implications for Policy. In: Luginaah, I.N. and Yanful, E.K. (Eds.) Environment and Health in SubSaharan Africa: Managing an Emerging Crisis, Springer Publishers, Netherlands, Pp 39-49. 
Ajayi, O.C., Place, F., Kwesiga, F., \& P. Mafongoya. 2007a. Impacts of Improved Tree Fallow Technology in Zambia. In: Waibel H. and Zilberman D (eds) International Research on Natural Resource Management: Advances in Impact Assessment CABI Wallingford, UK and Science Council/CGIAR, Rome pp.147-168 ISBN: 976-1-84593-283-1.

Ajayi, O.C., Akinnifesi, F.K., Gudeta, S. \& S. Chakeredza. 2007b. Adoption of renewable soil fertility replenishment technologies in southern African region: lessons learnt and the way forward Natural Resource Forum 31(4): 306-317

Ajayi, O.C. \& F. Kwesiga. 2003. Implications of local policies and institutions on the adoption of improved fallows in eastern Zambia Agroforestry systems 59 (3): 327-336

APCA. 2010. L'agroforesterie dans les règlementations agricoles. Etat des lieux en juin 2010. Assemblée Permanente des Chambres d'Agriculture (APCA), Paris, France, 17 pp.

Banful, A., Nkonya, E. \& V. Oboh. 2010. Constraints to Fertilizer Use in Nigeria: Insights from Agricultural Extension Service, IFPRI Discussion Paper 01010, International Food Policy Research Institute, Washington DC.

Boffa, J-M. 1999. Agroforestry parklands in Sub-Saharan Africa. FAO Conservation Guide 34, Food and Agriculture Organization, Rome.

Boshier, D., Cordero, J., Detlefsen, G., \& J. Beer. 2009. Indigenous trees for farmers: information transfer for sustainable management in Central America and the Caribbean. In Joseph, P. ed. Écosystèmes forestiers des Caraïbes. Conseil Général de La Martinique, Martinique, Karthala. p. 397 - 410.

Bond, W.J., Midgley, G.F. \& F.I. WoodwardI. 2003. The importance of low atmospheric $\mathrm{CO}_{2}$ and fire in promoting the spread of grasslands and savannas. Global Change Biology 9: 973-982.

Chitakira, M. \& E. Torquebiau. 2010. Barriers and Coping Mechanisms Relating to Agroforestry Adoption by Smallholder Farmers in Zimbabwe. Journal of Agricultural Education and Extension 16 (2): 147-160.

Cordero, J. \& D. Boshier. 2003. Árboles de Centroamérica: un manual para extensionistas. Oxford, Inglaterra, OFI - CATIE. $1079 \mathrm{p}$.

De Baets, N., Gariépy, S. \& A. Vézina. 2007. Portrait of agroforestry: Executive summary. Agriculture and Agri-Food Canada, Ottawa.

Detlefsen, G. \& M. Scheelje. 2011. Implicaciones de las normativas forestales para el manejo maderable sostenible en sistemas agroforestales de Centroamérica. Turrialba, Costa Rica, CATIE. 41 p.

Elbow, K. \& A. Rochegude. 1990. A layperson's guide to the forest codes of Mali, Niger, and Senegal. Land Tenure Center Paper No. 130. Madison, Land Tenure Center, University of Wisconsin-Madison.

FAOSTAT. 2011. Food and Agriculture Organization of the United Nations FAOSTAT Online Database, April-2011, accessed at http:/ / faostat.fao.org

FAO. 2003. Forestry outlook study for Africa: regional report for opportunities and challenges towards 2020. FAO Forestry Paper 141. FAO, Rome.

FAO. 2009. The Commission on Genetic Resources for Food and Agriculture Integrating the potential of forest genetic resources. FAO, Rome.

FAO. 2010. "Climate-Smart" Agriculture. Policies, Practices and Financing for Food Security, Adaptation and Mitigation. FAO, Rome, 41 p.

FAO, 2011a. A Thematic Study prepared in the framework of the Global Forest Resources Assessment 2010. Draft working paper, prepared and edited by H.de Foresta, in collaboration with G. Detlefsen and A. Temu. FAO Forest Assessment, Management and Conservation Division. September 2011. Rome, 210 p. 
FAO. 2011b. State of the World's Forests. FAO, Rome. 164 p.

Feder, G., Murgai, R., \& J. Quizon. 2003. Sending Farmers Back to School: The Impact of Farmer Field Schools in Indonesia. World Bank Policy Research Working Paper 3022, World Bank, Washington DC.

Franzel S. \& C. Wambugu. 2007. The uptake of fodder shrubs among smallholders in East Africa: key elements that facilitate widespread adoption. In: Hare MD, Wongpichet K, eds. Forages: a pathway to prosperity for smallholder farmers. Proceedings of an international symposium. Ubon Ratchathani University, Thailand: Faculty of Agriculture. p. 203-222.

Garrity, D.P., Akinnifesi, F.K., Ajayi, O.C., Weldesemayat, S.G., Mowo, J.G., Kalinganire, A., Larwanou, M., \& J.Bayala. 2010. Evergreen Agriculture: a robust approach to sustainable food security in Africa. Food Security 2:197-214

Government of Uganda. 2001. Uganda Forestry Policy, Uganda Forestry Authority, Government of Uganda, Entebbe.

Guillerme, S., Kumar, B.M., Menon, A., Hinnewinkel, C., Maire, E., \& A. Santhoshkumar. 2011. Impacts of Public Policies and Farmer Preferences on Agroforestry Practices in Kerala, India. Environmental Management 48: 351-364.

Haggblade, S., \& G. Tembo. 2003. Conservation farming in Zambia. EPTD Discussion Paper. Environment and Production Technology Division, International Food Policy Research Institute.

Hansen, J., Luckert, M., Minae, S., \& F. Place. 2005. Tree Planting Under Customary Tenure Systems in Malawi: An Investigation into the Importance of Marriage and Inheritance Patters. Agricultural Systems 84 (1): 99-118.

Kgope, B.S., Bond, W.J. \& G.F. Midgley. 2010. Growth responses of African savanna trees implicate atmospheric [CO2] as a driver of past and current changes in savanna tree cover. Australian Ecology 35: 451-463.

Leimona, B. 2011. Fairly Efficient or Efficiently Fair: success factors and constraints of payment and reward schemes for environmental services in Asia. Phd Thesis, Graduate School of Socio-Economic and Natural Sciences of the Environment, Wageningen University, Netherlands.

Midgley, G.F. \& W. Thuillier. 2011. Potential responses of terrestrial biodiversity in Southern Africa to anthropogenic climate change. Regional Environmental Change 11 (Suppl 1): S127-S135. DOI 10.1007/s10113-010-0191-8

Organic Research Centre. 2010. Agroforestry Policy Review. UK, Elm Farm, 28 p.

Ostrom, E. 1990. Governing the Commons: the Evolution of Institutions for Collective Action. Cambridge, U.K.: Cambridge University Press.

Otsuka, K. \& F. Place. 2001. Issues and Theoretical Framework, in K. Otsuka and F. Place, Land Tenure and Natural Resource Management: A comparative study of agrarian communities in Asia and Africa. Baltimore: Johns Hopkins Press.

Pangapanga, P.I. \& O.C. Ajayi. 2011 Review of National Agroforestry Policy: Malawi Case Study Report, Working Paper, World Agroforestry Centre, Malawi 29 pp.

Pender, J., Suyanto, S., \& J. Kerr. 2008. Impacts of the Hutan Kamasyarakatan Social Forestry Program in the Sumberjaya Watershed, West Lampung District of Sumatra, Indonesia, IFPRI Discussion Paper 00769, International Food Policy Research Institute, Washington, DC.

Place, F. 1995. The Role of Land and Tree Tenure on the Adoption of Agroforestry Technologies in Uganda, Burundi, Zambia, and Malawi: A Summary and Synthesis, Madison, Wisconsin: Land Tenure Center, University of Wisconsin. 
Place, F. \& P. Dewees. 1999. Policies and incentives for the adoption of improved fallows. Agroforestry Systems, 47(1/3): 323-343.

Place, F. \& K. Otsuka. 2001. Tenure, Agricultural Investment, and Productivity in the Customary Tenure Sector of Malawi. Economic Development and Cultural Change, 50(1).

Place, F. \& B. Swallow. 2002. "Assessing the Relationships between Property Rights and Technology Adoption in Smallholder Agriculture: Issues and Empirical Methods," in Meinzen-Dick, R., Knox, A., Place, F., and B. Swallow. Innovation in Natural Resource Management: The Role of Property Rights and Collective Action in Developing Countries, Johns Hopkins University Press, Baltimore, USA.

Pye-Smith C. 2009. Seeds of Hope: A public-private partnership to domesticate a native tree, Allanblackia, is transforming lives in rural Africa.Nairobi: World Agroforestry Centre.

Pye-Smith C. 2010. A Rural Revival in Tanzania: How agroforestry is helping farmers to restore the woodlands in Shinyanga Region. ICRAF Trees for Change no. 7. Nairobi: World Agroforestry Centre.

Reij, C., Tappan, G. \& M. Smale. 2009. Agroenvironmental Transformation in the Sahel. Another Kind of Green Revolution. IFPRI Discussion Paper 00914, International Food Policy Research Institute, Washington, DC.

Sanchez, A. P. 1999. Improved fallows come of age in the tropics. Agroforestry Systems, 47: 3-12.

Smith, P. \& D. Martino. 2007. Agriculture, in Climate Change 2007, Fourth IPCC Assessment Report, IPCC, Geneva, Switzerland

Smith, P., Martino, D., Cai, Z., Gwary, D., Janzen, H., Kumar, P., McCarl, B., Ogle, S., O'mara, F., Rice, C., Scholes, B., Sirotenko, O., Howden, M., McAllister, T., Pan, G., Romanenkov, V., Schneider, S. Towprayoon, U., Wattenbach, M. \& J. Smith 2008. Greenhouse-gas mitigation in agriculture. Philosophical Transactions of the Royal Society, B., 363: 789-813.

Sturmheit, P. 1990. Agroforestry and soil conservation needs of smallholders in southern Zambia, Agroforestry systems, 10: 265-289

Torquebiau, E. \& H. Moussa. 1990. Potentialités agroforestières pour la zone semi-aride du Niger. Rapport AFRENA N²5, ICRAF, Nairobi, 134 pp.

Torquebiau, E. \&t H. Moussa. 1991. Propositions de recherches agroforestières pour le système de la vallée du fleuve Niger au Niger. Rapport AFRENA N 39, ICRAF, Nairobi, 93 pp.

USDA 2011. USDA Agroforestry Strategic Framework, Fiscal Year 2011-2016. United States Department of Agriculture, Washington, $.35 \mathrm{p}$.

Williams,S.E., van Noordwijk, M., Penot, E., Healey, J.R., Sinclair, F.L., \& G. Wibawa. 2001. On-farm evaluation of the establishment of clonal rubber in multistrata agroforests in Jambi, Indonesia. Agroforestry Systems 53: 227-237.

Zomer, R. J., Bossio, D. A., Trabucco, A., Yuanjie, L., Gupta, D. C., \& V.P. Singh. 2007. Trees and water: Smallholder agroforestry on irrigated lands in Northern India. Colombo, Sri Lanka: International Water Management Institute. 47p. (IWMI Research Report 122).

Zomer, R.J., Trabucco, A., Coe, R., \& F. Place. 2009. Trees on farm: Analysis of global extent and geographical patterns of agroforestry. ICRAF, Working Paper no. 89. Nairobi, Kenya, ICRAF. 63 pgs. 
AGROFORESTRY FOR

BIODIVERSITY AND

ECOSYSTEM SERVICES

SCIENCE ANO PRACTICE

Ededa by Murts Leckion Kionga

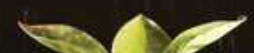

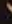

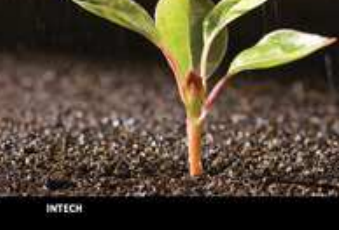

\section{Agroforestry for Biodiversity and Ecosystem Services - Science and Practice}

Edited by Dr. Martin Kaonga

ISBN 978-953-51-0493-3

Hard cover, 164 pages

Publisher InTech

Published online 04, April, 2012

Published in print edition April, 2012

Agroforestry has great potential for reducing deforestation and forest degradation, providing rural livelihoods and habitats for species outside formally protected land, and alleviating resource-use pressure on conservation areas. However, widespread adoption of agroforestry innovations is still constrained by a myriad of factors including design features of candidate agroforestry innovations, perceived needs, policies, availability and distribution of factors of production, and perception of risks. Understanding the science, and factors that regulate the adoption, of agroforestry and how they impact the implementation of agroforestry is vitally important. Agroforestry for Biodiversity and Ecosystem Services: Science and Practice examines design features and management practices of some agroforestry practices and their impact on biodiversity and the ecosystem services it delivers. It also identifies policy issues for facilitating adoption of desirable agroforestry practices and gradual diminution of undesirable policies.

\section{How to reference}

In order to correctly reference this scholarly work, feel free to copy and paste the following:

Frank Place, Oluyede C. Ajayi, Emmanuel Torquebiau, Guillermo Detlefsen, Michelle Gauthier and Gérard Buttoud (2012). Improved Policies for Facilitating the Adoption of Agroforestry, Agroforestry for Biodiversity and Ecosystem Services - Science and Practice, Dr. Martin Kaonga (Ed.), ISBN: 978-953-51-0493-3, InTech, Available from: http://www.intechopen.com/books/agroforestry-for-biodiversity-and-ecosystem-servicesscience-and-practice/improved-policies-for-facilitating-the-adoption-of-agroforestry

\section{INTECH}

open science | open minds

\section{InTech Europe}

University Campus STeP Ri

Slavka Krautzeka 83/A

51000 Rijeka, Croatia

Phone: +385 (51) 770447

Fax: +385 (51) 686166

www.intechopen.com

\section{InTech China}

Unit 405, Office Block, Hotel Equatorial Shanghai

No.65, Yan An Road (West), Shanghai, 200040, China

中国上海市延安西路65号上海国际贵都大饭店办公楼 405 单元

Phone: +86-21-62489820

Fax: $+86-21-62489821$ 
(C) 2012 The Author(s). Licensee IntechOpen. This is an open access article distributed under the terms of the Creative Commons Attribution 3.0 License, which permits unrestricted use, distribution, and reproduction in any medium, provided the original work is properly cited. 